\title{
Statistical optimization of bioactive metabolite production from Bacillus cereus NSD 10072 by using low cost substrate
}

\author{
Namita Singh ${ }^{1}$, Rajneesh Jaryal ${ }^{1}$, Shweta ${ }^{1}$, Anita Devi ${ }^{1}$, Suryakant Panchal ${ }^{1}$, \\ Pallavi Thakur ${ }^{1,2}$ \\ Corresponding author: ${ }^{1}$ Dr Namita Singh, Microbial Biotechnology laboratory, Department of Bio \& \\ Nano Technology, Guru Jambheshwar University of science \& Technology, Hisar, Haryana, India-125001 \\ ${ }^{2}$ Division of CBRN Defence, Institute of Nuclear Medicine and Allied Sciences, Delhi - 110054, India
}

\begin{abstract}
Natural bioactive compounds are better than synthesised chemical compound. As the overuse \& misuse of certain antibiotics have led to adverse environmental effects and raised public concerns. Bacteria are considered as the most common source of natural bioactive compounds. In the present study isolated bacterial strain Bacillus cereus NSD 10072 had been used. Bacterial strain has antimicrobial activity against both Gram positive and Gram negative bacteria which act as common human pathogens. Different low cost substrate was used and best growth of the bacterium was found in animal feed supplemented with minimal media. Total organic carbon, Protein and total solid content of substrate used were found $0.0340 \%, 13.363 \mu \mathrm{g} / \mathrm{ml}$ and $0.0466 \%$ respectively. Metal ions $\mathrm{Fe}, \mathrm{Zn}, \mathrm{Cd}, \mathrm{Pb}$ and $\mathrm{Cu}$ were found in the substrate by using atomic absorption spectrum. For the isolated strain growth conditions were optimised using response surface methodology. Maximum growth and antibacterial activity was obtained by bacterial strain at $34^{\circ} \mathrm{C}$ after $54 \mathrm{hrs}$ and at $160 \mathrm{rpm}$. Hence, the isolated strain is a potent source of antimicrobial activity and can be used in the field of food, feed, cosmetic and preservative industries.
\end{abstract}

Keywords: Antimicrobial, Bacillus, RSM, Pathogen, bioactive compound

\section{INTRODUCTION}

Throughout the ages, natural products have been the most consistently successful source of lead compounds that have found many applications in the fields of medicine, pharmacy and agriculture. Microbial natural products have been the source of most of the antibiotics in current use for the treatment of various infectious diseases. Their advent changed the outlook of the physician about the power, drugs can have on diseases. Their importance is magnified in the developing countries where infective diseases predominate (Tripathi 2008). These may be effective against infectious diseases as well as different bacterial infections (Finglaset al., 2003, Berdy 2005).Bioactive metabolites are the natural substances produced by various species of microorganisms which in low concentration selectively suppress the growth of or kill other species of microorganisms (Singh and Kapoor2005). These metabolites are heterogeneous group of small amino acids produces as immune response to inhibit other life forms. These can be de novo designed or synthetically produced by the microorganisms (Galdieroet al., 2015). Bacteriocins are synthesized as prepeptide which are processed to active peptide and externalised by dedicated transport machinery (Neset al., 1996). They show several desired features to biotechnological applications, and they could be used in combined therapy or as substitute of conventional antibiotics in the control of bacterial infections. All the organisms under eukaryotes and the prokaryotes have ability to produce ribosomally synthesized antimicrobials peptides. Antimicrobial peptides have been found in all major lineages of bacteria (Riley and Wertz 2002) and isolated from various sources as microorganisms, plants, insects, amphibians and mammals (Riley 2007; Chavanet al., 2007). In bacteria such antimicrobials peptides includes heterogeneous array of molecules that may be inhibitory either for themselves or for other bacteria. These molecules include toxins, bacteriolytic enzymes, bacteriophages, by products of primary metabolites, antibiotics, bacteriocin and bacteriocin like substances. The bacteriocin family is the most abandoned and diverse group of bacterial defense system (Riley and Wertz 2002).Bacteriocin is synthesized first as pre- propeptide which contain an N-terminal extension or leader sequence (termed double glycine leader) and are biologically inactive. They are processed and externalized by transport machinery (Neset al., 1996). The production of bacteriocins has been already described for many Bacillus species such as Bacillus cereus, Bacillus subtilis and Bacillus thuringiensis due to its structural and genetic complexity (Claderaet al., 2004). For cost- effective production, agro industrial wastes are used as substrates (Razacket al., 2013). Optimization of medium by the classical method involves changing one independent variable by fixing all others at a fixed level. This is extremely time consuming and expensive for a large no. of variables and also may result in wrong conclusions. Response surface methodology (RSM) is a collection of statistical techniques for designing experiments, building models, evaluating the effects of factors, and searching optimum conditions of factors for 
desirable responses. This method was successfully applied in many areas of biotechnology, including some recent studies on bacteriocin production (Claderaet al.,2004). The present study is meant to optimize the components for the production of bacteriocins from Bacillus using synthetic agro wastes (poultry feed, mustard oil cakes, animal feed) as carbon substrates (Razacket al.,2013).

\subsection{Microorganism}

\section{MATERIAL \& METHODS}

Bacterial strain MTCC 10072 (isolated in lab) is used. Culture is maintained in Trypton Soya Broth (TSB) $34{ }^{\circ} \mathrm{C}$ by sub-culturing every $1-2$ weeks.

\subsection{Collection of sample}

Following samples were collected for investigation -Poultry feed, Sarson oil Cakes, Groundnut peel, Whey, Millet, Animal Feed (Khal). Samples were collected from B D Cotton Mill (BD Cotton Mills Private limited, 7 K.M., Sirsa Road, Hisar, 125001, Haryana, India). Collected samples were dried in oven at $50^{\circ} \mathrm{C}$, grinded and then kept in the air tight containers for further study (Figure 1).

\subsection{Ash content determination of animal feed}

Crucible was weighed accurately to $0.1 \mathrm{mg}$. $1 \mathrm{gm}$ of the oven dried sample was weighed into the crucible and weight of crucible with sample was recorded. Sample was Ignited the in a muffle furnace at $600^{\circ} \mathrm{C}$ for $2 \mathrm{hr}$ to obtain white ash. Crucible was transferred to a dessicator, allowed to cool down at room temperature and weighed. Total ash content was determined according to the formula-

$$
\begin{aligned}
& \text { Ash }(\%)= \\
& (\text { Weight of crucible }+ \text { ash })-(\text { weight of empty crucible }) \times 100 \\
& \text { Initial sample weight }
\end{aligned}
$$

\subsection{Metal ions detection in animal feed}

Substrate (animal feed) was digested with nitric acid and perchloric Acid (3:1) by placing the sample on the water bath. White precipitates observed after digestion was dissolved in double distilled water and filtered $(0.45 \mu \mathrm{mfilter})$. Digested sample was analyzed for the presence of various metals in atomic absorption spectroscopy (GCB 932+).

\subsection{Optimization of carbon source}

Bacterial colonies from TSB were transferred to $100 \mathrm{ml}$ minimal media (Ericson and Ricke 1999), in which glucose $(1 \%)$ has been replaced with substrates $(1 \%)$ like- poultry feed, animal feed, whey, mustard oil cakes, groundnut peel, whole wheat and millet in separate flasks and growth was observed. Flasks were incubated overnight at $30^{\circ} \mathrm{C}$ and analyzed for bacterial growth.

\subsection{Antibacterial Metabolite extraction}

Bacterial colonies from TSB were transferred to minimal media $(100 \mathrm{ml})$ supplemented with animal feed $(1 \%)$ and incubated overnight at $30^{\circ} \mathrm{C}$.After incubation content of flask was centrifuged at 12,000 RPM for $10 \mathrm{~min}$ at $4^{\circ} \mathrm{C}$. Supernatant was used for determination of antibacterial activity.

\subsection{In vivo assay/ screening of inhibitory activity of antibacterial strain}

Agar well diffusion method was used to determine the ability of bacterial isolate to inhibit the growth of sensitive pathogen that is staphylococcus aureusNCIM 5021. 30 $\mu 1$ sample was poured into the wells against overnight grown culture of Staphylococcus aureus NCIM 5021.

\subsection{Optimization of Assay Condition using RSM Approach}

Further optimization for bacterial growth and antibacterial activity was carried by response surface methodology (RSM) using a Box- Behnken design of experiments. For it three most significant factors [Incubation temperature (A), Incubation time (B), Rotation per Minute (C)] were chosen. Each variable was studied at three different levels $(-1,0,+10)$ and 17 experiments were carried out in total (Box and Behnken, 1960), (Table 1).

\subsection{Partial purification of antimicrobial compound}

\subsubsection{Ammonium sulphate precipitation}

Bacterial strain was cultured at $37^{\circ} \mathrm{C}, 120 \mathrm{rpm}$ for $72 \mathrm{hrs}$ in TSB. Culture was centrifuged at $7000 \mathrm{rpm}$ for 10 min at $4^{\circ} \mathrm{C}$. Metabolite in cell free supernatant containing antibacterial activity was precipitated with $\left(\mathrm{NH}_{4}\right)_{2} \mathrm{SO}_{4}$ to three cut off $(0-30 \%, 30-75$ and $75-80 \%)$. Precipitation was carried out in a refrigerator by addition of small 
amount of ammonium sulphate with constant stirring. Mixtures were centrifuged at $10000 \mathrm{rpm}$ for $20 \mathrm{~min}$ at $4^{\circ} \mathrm{C}$. The precipitates collected from all cut offs were dissolved in a small volume of sodium phosphate buffer (20mM, pH 7.0) and analyzed for antibacterial activity.

\subsubsection{Dialysis}

Membrane was activated by boiling it in $10 \mathrm{mM}$ EDTA and a pinch of $\mathrm{NaHCO}_{3}$ solution for 30 minutes to chelate the ions present on the dialysis membrane. Fraction of ammonium sulphate precipitation showing highest antibacterial activity was dialyzed against sodium phosphate buffer (20mM, pH 7.0). Removal of salt was confirmed by absence of precipitation of $\mathrm{BaSO}_{4}$ in the Buffer. Butanolic extract was formed of the dialysed sample and antibacterial activity was checked.

\section{RESULT \& DISCUSSION}

\subsection{Optimization of carbon source}

Minimal media supplemented with animal feed was found to be the best media for bacterial growth. The media was further used for extraction of metabolite for antibacterial activity.

\subsection{Ash content and metal ions determination of animal feed}

Total solid content of animal feed was found to be $0.0340 \%$. Analyzed sample contains found to contain the different heavy metal ions (Table 2)

\subsection{Optimization of Production Conditions using RSM}

In addition to analyzing the effects of the independent variables, this experimental methodology generates a mathematical model which describes the chemical or biochemical processes (Anjumet al. 1997; Myers and Montgomery 1995). Every organism has optimum conditions beyond which the bacterial growth decreases. In the lag phase bacterial growth is slow, it is highest at optimum condition that is in the log phase. Incubation time, incubation temperature and agitation are the most significant factors determining the growth and hence activity of a bacterial strain. Selected bacterial strain was found to show maximum growth after 54 hrs of incubation at temperature $34^{\circ} \mathrm{C}$ and $160 \mathrm{rpm}$. According to the theoretical study, as the incubation time increases, the bacterial growth increases up to a level, that is in log phase and then decreases. Agitation plays an important role regarding bacterial growth. As agitation increases there is continuous dissolution of nutrients and there is proper supply of oxygen to the bacteria. The toxic chemicals produced during the incubation time do not concentrate at a place and thus do not hinder the bacterial growth. It is also well documented as the temperature increases the growth increases giving a bell shaped curve and then decreases. High temperature may kill the cells and thus not favorable for the growth. 3D response surface plots were plotted to study the interaction between three independent variables selected to determine the optimum conditions for achieving maximum growth (Fig. 2). The coordinates of the central point in highest contour levels in each figure communicate to the optimum condition of the relevant components. Elliptical nature of observed plots indicates an interactive effect of variables studied on predicted response. A multiple regression analysis of the data was carried out for obtaining an empirical model that relates the response measured to the independent variables. A second order polynomial equation for a three factor system is:

$$
\mathrm{Y}_{\mathrm{i}}=\mathrm{a}_{0}+\sum \mathrm{a}_{\mathrm{i}} \mathrm{X}_{\mathrm{i}}+\sum \mathrm{a}_{\mathrm{ii}} \mathrm{X}_{\mathrm{ii}}^{2}+\sum \mathrm{a}_{\mathrm{ij}} \mathrm{X}_{\mathrm{i}} \mathrm{X}_{\mathrm{j}}+\mathrm{e}
$$

Where, $Y_{i}$ is the response i.e. activity of bacteria, $a_{0}$ is the constant coefficient, $a_{i}$ is the $i^{\text {th }}$ linear coefficient, $a_{i i}$ is the $\mathrm{i}^{\text {th }}$ quadratic coefficient and $\mathrm{a}_{\mathrm{ij}}$ is the different interaction coefficients of the model; $\mathrm{X}_{\mathrm{i}} \mathrm{X}_{\mathrm{j}}$ are the coded independent variables related to the factors, and e is the error of model.

\subsection{Validation of Response Surfacemodels and statistical analysis}

The relationship between independent variables and the response was drawn by the second order polynomial equations. The regression equation coefficients were calculated and the data was fitted to a secondorder polynomial equation. The response, bacterial activity can be expressed in terms of following regression equations.

Bacterial Growth $=+0.89+0.059^{*} \mathrm{~A}-0.080{ }^{*} \mathrm{~B}+0.16^{*} \mathrm{C}-1.900 \mathrm{E}-003 * \mathrm{AB}-0.13 * \mathrm{AC}+0.093^{*} \mathrm{BC}-0.061^{*}$ $\mathrm{A}^{2}-0.19 * \mathrm{~B}^{2}-0.087 * \mathrm{C}^{2}$

In which $\mathrm{A}$ is the rotation per minute, $\mathrm{B}$ is incubation time (hours) and $\mathrm{C}$ is incubation temperature $\left({ }^{\circ} \mathrm{C}\right)$.

Statistical testing of the model was performed with the Fisher's statistical test for analysis of variance (ANOVA). Very high degree of quadratic regression showed that the model was significant because the value of F- test (the ratio of mean square due to regression to mean squares due to real error) less than 0.05 indicated the significance of the model terms (Table 3). The non-significant value of lack of fit (more than 0.1000) showed that the quadratic model was valid for the present study. The closer the $\mathrm{R}^{2}$ value is to 1.0 , the stronger the model and better it predicts the response. The adjusted $\mathrm{R}^{2}$ value of 0.9008 suggested that model was significant. A very 
low value of coefficient of variation (C.V.) $8.63 \%$ clearly indicated precision and a good deal of reliability of the experiment values (Table 4). The Model F-value of 17.14 implies the model is significant. There is only a $0.06 \%$ chance that an F-value this large could occur due to noise. Values of "Prob> F" less than 0.0500 indicate model terms are significant. In this case $\mathrm{A}, \mathrm{B}, \mathrm{C}, \mathrm{AC}, \mathrm{BC}, \mathrm{B}^{\wedge} 2, \mathrm{C}^{\wedge} 2$ are significant model terms. Values greater than 0.1000 indicate the model terms are not significant. If there are many terms in the model and the sample size is not very large, the adjusted $\mathrm{R}^{2}$ may be noticeably smaller than predicted $\mathrm{R}^{2}$. The value of coefficient of determination $\left(\mathrm{R}^{2}\right)$ was 0.9566, adjusted $\mathrm{R}^{2}$ was 0.9608, "Pred R-Squared" of 0.9526, Adeq Precision of 14.527. Adeq Precision" measures the signal to noise ratio. A ratio of Adeq precision greater than 4 is desirable.

\subsection{Screening for antibacterial activity for the isolated strain}

Antibacterial activity of the isolated strain was assayed by well diffusion method. Isolated strain had shown antibacterial zone of inhibition (6mm) against Staphylococcus aureus NCIM 5021(Fig. 3).

\subsection{Extraction of Antibacterial compound from crude supernatant}

Active antibacterial metabolite was found to present in cell free supernatant of culture with the $80 \%$ ammonium sulphate salt. Precipitated proteins were dissolved in $20 \mathrm{mM}$ sodium phosphate buffer and dialyzed against the same buffer. Antibacterial activity was checked of dialysed sample (Fig.4) and its butanolic extract (Fig.5). $30 \mu 1$ sample was poured into the wells and $9 \mathrm{~mm}$ and $13 \mathrm{~mm}$ zone of inhibition against Staphylococcus aureus NCIM 5021 was found in dialysed and its butanolic extract respectively.

\section{FIGURES AND TABLES}

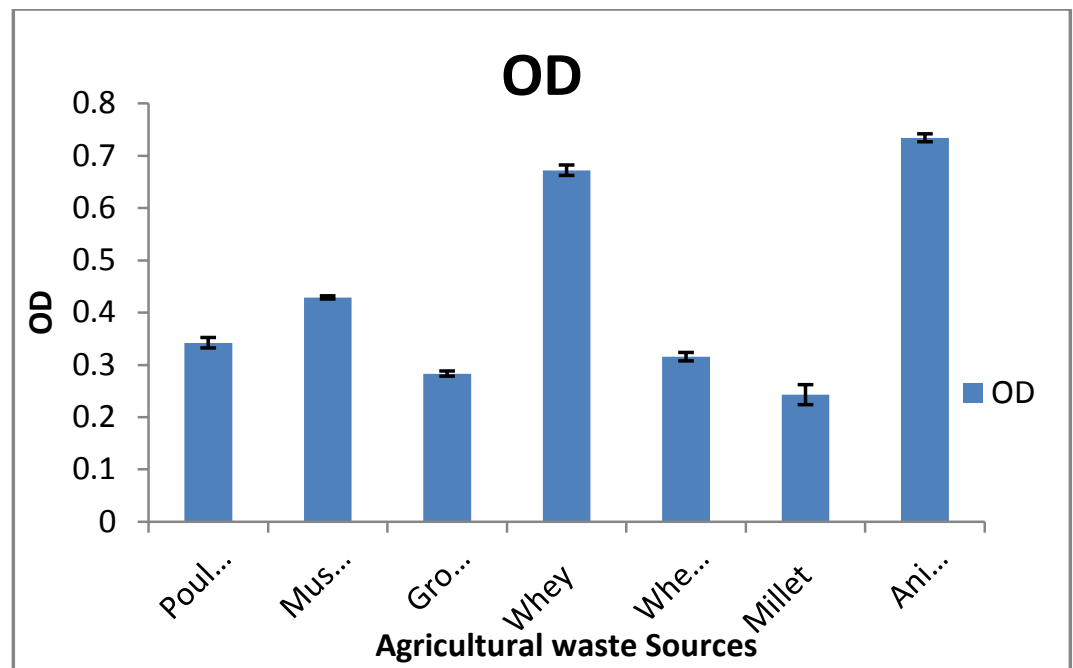

Fig. 1: comparative growth of Bacillus cereus NSD 10072 in selected agricultural wastes

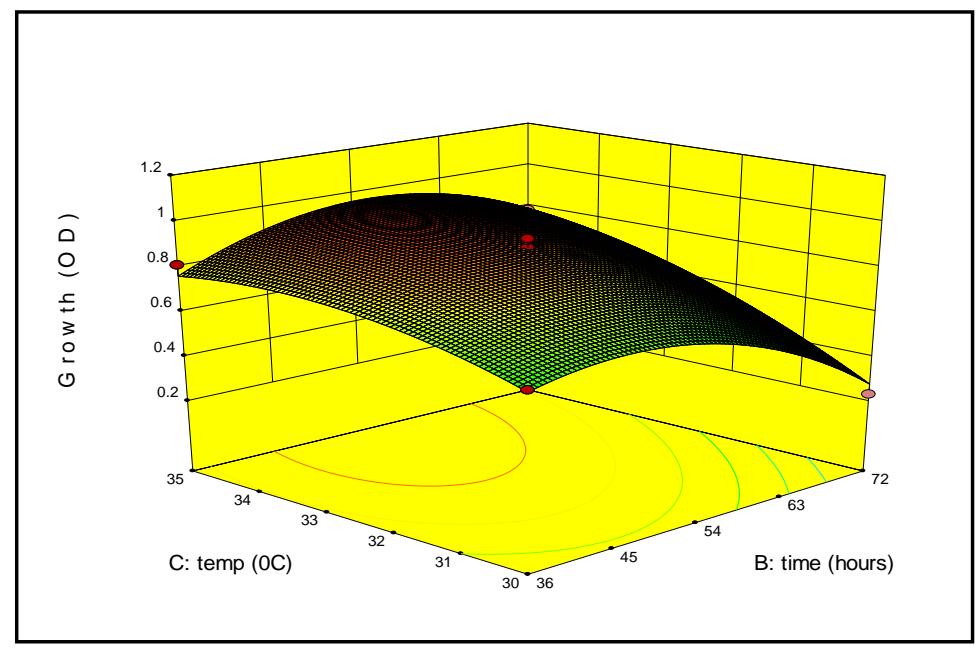

a) 


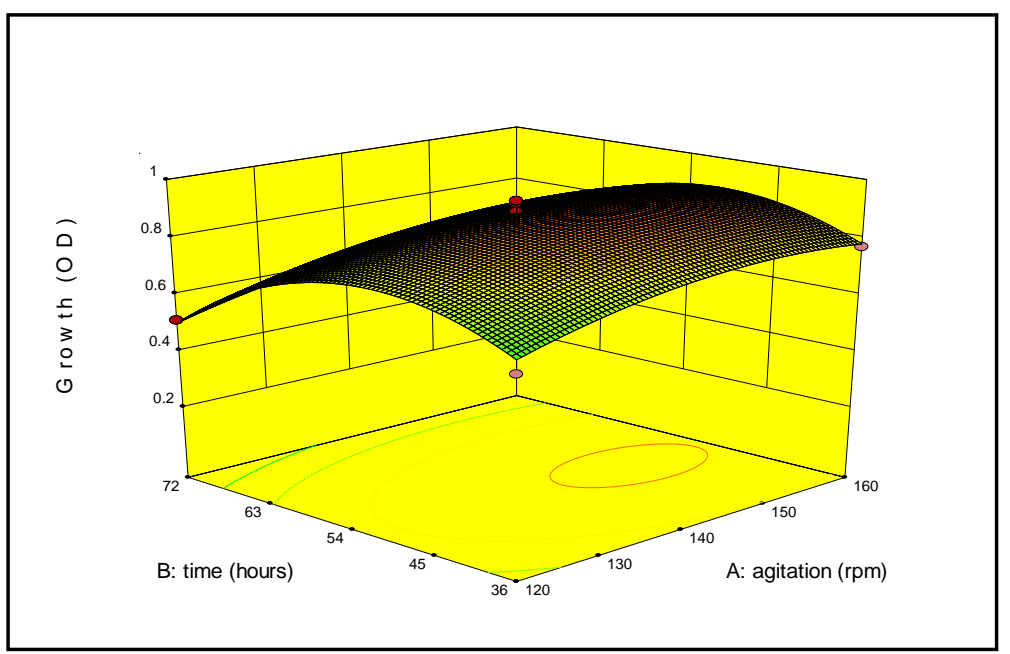

b)

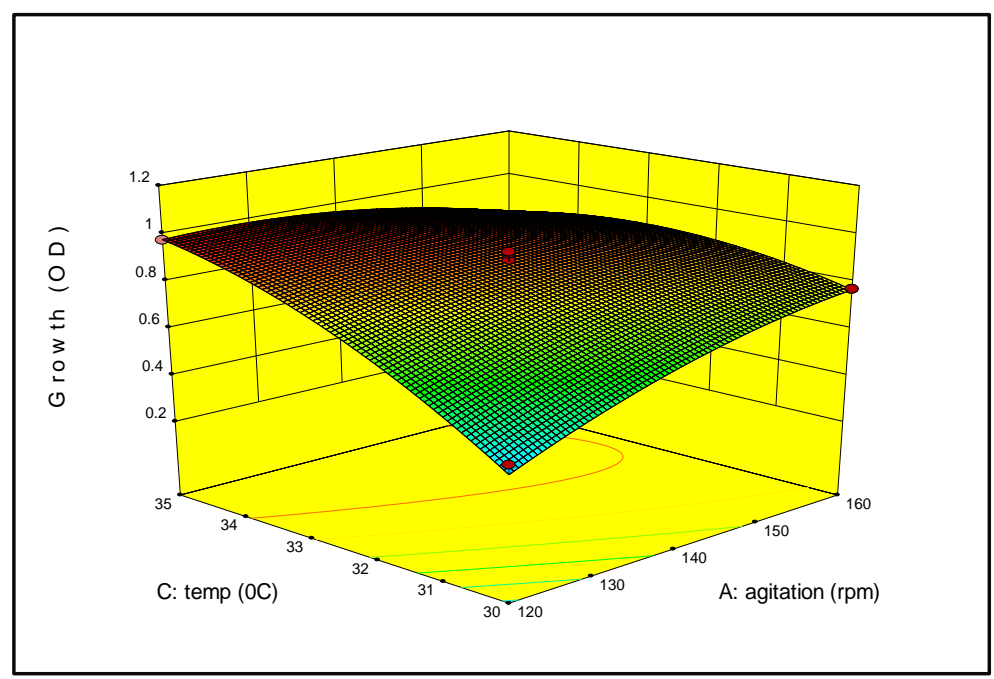

c)

Figure 2:3D plots showing the interactive effect of a) incubation time and incubation temperature b) Incubation time and agitation and c) incubation temperature and agitation on bacterial growth

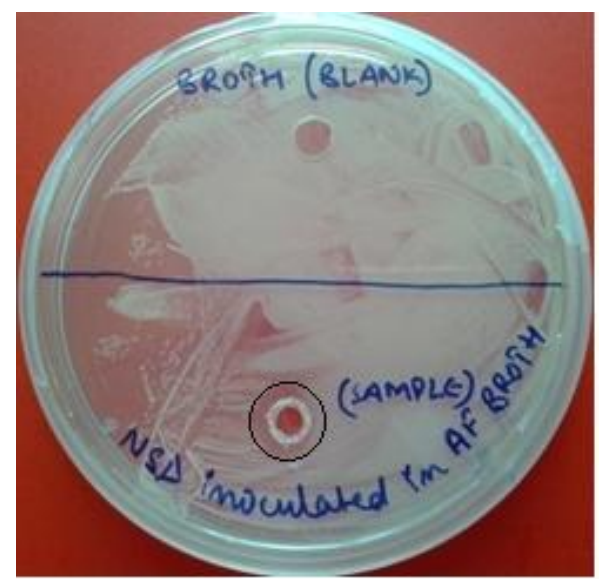

Fig 3: Zone of inhibition bacteria inoculated in medium (animal feed in minimal media) 


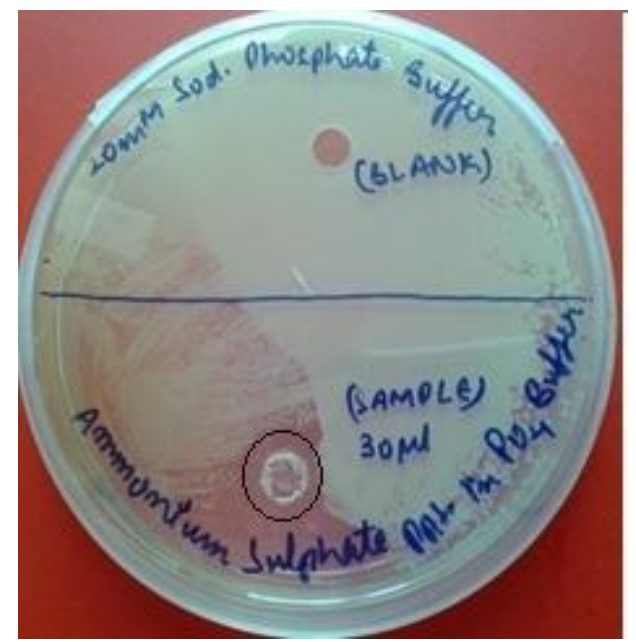

Fig 4: Zone of inhibition of dialysed sample

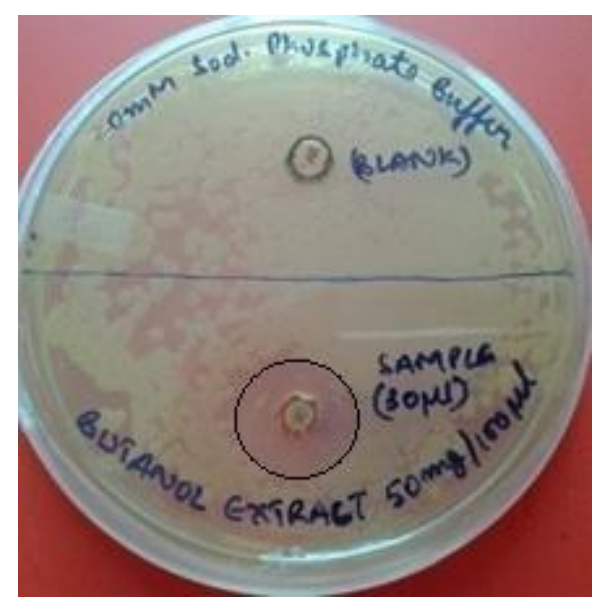

Fig 5: Zone of inhibition of butanolic extract of dialysed sample

Table 1: Box Behnken design to study the effect of three independent variables on bacterial activity

\begin{tabular}{|c|c|c|c|c|c|}
\hline \multirow[t]{2}{*}{ Run } & \multirow{2}{*}{$\begin{array}{l}\text { Rotation per } \\
\text { minute } \\
(\mathrm{rpm})\end{array}$} & \multirow{2}{*}{$\begin{array}{l}\text { Incubation } \\
\text { time } \\
\text { (Hrs.) }\end{array}$} & \multirow{2}{*}{$\begin{array}{l}\text { Incubation } \\
\text { temperature } \\
\left({ }^{\circ} \mathrm{C}\right)\end{array}$} & \multicolumn{2}{|l|}{ Response } \\
\hline & & & & $\begin{array}{l}\text { Bacterial } \\
\text { Growth (OD) }\end{array}$ & $\begin{array}{l}\text { Inhibition } \\
\text { zone (mm) }\end{array}$ \\
\hline 1 & 140 & 54 & 32.5 & 0.618 & 3.6 \\
\hline 2 & 140 & 36 & 30 & 0.326 & 1.8 \\
\hline 3 & 140 & 72 & 35 & 0.712 & 5.0 \\
\hline 4 & 160 & 54 & 35 & 0.893 & 6.0 \\
\hline 5 & 120 & 54 & 35 & 0.645 & 4.6 \\
\hline 6 & 160 & 54 & 30 & 0.711 & 5.0 \\
\hline 7 & 140 & 54 & 32.5 & 0.643 & 4.6 \\
\hline 8 & 120 & 36 & 32.5 & 0.592 & 4.3 \\
\hline 9 & 140 & 72 & 30 & 0.514 & 3.8 \\
\hline 10 & 120 & 54 & 30 & 0.414 & 2.6 \\
\hline 11 & 140 & 54 & 32.5 & 0.568 & 4.0 \\
\hline 12 & 140 & 54 & 32.5 & 0.568 & 4.0 \\
\hline 13 & 140 & 54 & 32.5 & 0.568 & 4.0 \\
\hline 14 & 140 & 36 & 35 & 0.524 & 3.6 \\
\hline 15 & 160 & 36 & 32.5 & 0.486 & 3.2 \\
\hline 16 & 160 & 72 & 32.5 & 0.635 & 4.4 \\
\hline 17 & 120 & 72 & 32.5 & 0.612 & 4.2 \\
\hline
\end{tabular}


Table 2: Concentration of metal ions

\begin{tabular}{|l|l|}
\hline Metal & Concentration $(\boldsymbol{\mu g} / \mathbf{m l})$ \\
\hline $\mathrm{Fe}$ & 0.199 \\
\hline $\mathrm{Zn}$ & 0.028 \\
\hline $\mathrm{Cd}$ & 0.003 \\
\hline $\mathrm{Pb}$ & 0.067 \\
\hline $\mathrm{Cu}$ & 0.007 \\
\hline
\end{tabular}

Table 3:ANOVA for Response Surface Quadratic model (DF = degree of freedom)

\begin{tabular}{|l|l|l|l|l|l|}
\hline Source & Sum of Squares & DF & Mean square & F value & p- value Prob> F \\
\hline Model & 0.61 & 9 & 0.068 & 17.14 & 0.0006 (significant) \\
\hline Lack of Fit & $33.989 \mathrm{E}-003$ & & 0.012 & 1.01 & $\begin{array}{l}0.4768 \text { not } \\
\text { significant }\end{array}$ \\
\hline A- agitation & 0.028 & 1 & 0.028 & 7.02 & 0.0330 \\
\hline B- time & 0.051 & 1 & 0.051 & 12.91 & 0.0088 \\
\hline C- Temp & 0.21 & 1 & 0.21 & 53.92 & 0.0002 \\
\hline AB & $1.444 \mathrm{E}-005$ & 1 & $1.444 \mathrm{E}-005$ & $3.633 \mathrm{E}-003$ & 0.9536 \\
\hline AC & 0.072 & 1 & 0.072 & 18.08 & 0.0038 \\
\hline BC & 0.035 & 1 & 0.035 & 8.79 & 0.0210 \\
\hline$A^{\wedge} 2$ & 0.016 & 1 & 0.016 & 3.97 & 0.0865 \\
\hline$B^{\wedge} 2$ & 0.15 & 1 & 0.15 & 37.33 & 0.0005 \\
\hline$C^{\wedge} 2$ & 0.032 & 1 & 0.032 & 8.01 & 0.0254 \\
\hline
\end{tabular}

Table 4: Analysis of variance table (CV= Coefficient of variation, PRESS $=$ Predicted sum of squares)

\begin{tabular}{|l|l|l|l|}
\hline Std. Dev. & 0.063 & R- Squared & 0.9666 \\
\hline Mean & 0.73 & Adj. R- Squared & 0.9608 \\
\hline C.V. $\%$ & 8.63 & Pred. R- Squared & 0.9526 \\
\hline PRESS & 0.22 & Adeq Precision & 14.527 \\
\hline
\end{tabular}

\section{CONCLUSION}

On the basis of present study, it can be concluded that the isolated bacterial strain identified as a potent source of antimicrobial activity can have future applications in the field of food/ feed industries. It can be used as preservative to improve the quality. It shows desired features to Biotechnological applications, and it can be used in combined therapy or as a substitute of the conventional antibiotics in the control of the bacterial infections.

\section{ACKNOWLEDGEMENT}

Author acknowledge HSCST, DBT and UGC-SAP for financial suport in the form of fellowship.

\section{REFERENCES:}

[1] K.D. Tripathi, Antimicrobial Drugs: General Considerations. Essential of Medical Pharmacology $6^{\text {th }}$ Edition 2008, 49- 667.

[2] P.M. Finglas, A.J. Wright, C.A. Wolfe, D.J. Hart, D.M. Wright, J.R. Dainty, Is there more to folates than neural-tube defects? ProcNutrSoc62, 2003, 591-598.

[3] J. Berdy, Bioactive microbial metabolites. A personal view.JAntibiot 58, 2005, 1-26.

[4] H. Singh, and V.K. Kapoor, Medicinal and Pharmaceutical Chemistry. 2nd edition. 2005, Delhi, India: VallabhPrakashan.

[5] S. Galdiero, A.Falanga, R. Berisio, P. Grieco, G. Morelli, and M. Galdiero, Antimicrobial peptides as an opportunity against bacterial diseases. Curr. Med. Chem 22(14), 2015, 1665-1677.

[6] I.F. Nes, D.B. Diep, L.S. Havarstein, M.B. Brurberg, V. Eijsink, and H. Holo, Biosynthesis of bacteriocins in lactic acid bacteria. Antoine Van Leeuwenhoek 70, 1996, 113-128.

[7] M.A. Riley, and J.E. Wertz, Bacteriocin: Evolution, Ecology and Application. Annu Rev Microbio.56, 2002, 117-37.

[8] M.A. Riley, Molecular mechanisms of Bacteriocins evolution. Annu Rev Genet 32, 2007, 255-78. 
[9] M.A. Chavan, and M.A. Riley, Molecular Evolution of Bacteriocins in Gram-Negative Bacteria, In:Bacteriocins: EcolEvol, 2007, pp. 5-18

[10] F.O. Cladera, G.R. Caron, A.A. Brandelli, Bacteriocin production by Bacillus licheniformisstrain P40 in cheese whey using response surface methodology. BiochemEng J 21, 2004,53-58.

[11] A.S. Razack, V. Velayutham, and V. Thangavelu, Medium optimization for the production of exopolysaccharides by Bacillus subtilis using synthetic sources and agro wastes.Turkish J. Bio 37, 2013, 280- 288.

[12] G.E.P. Box, and D.W. Behnken, Some new three level designs for the study of quantitative variables.Technometrics 2, 1960, 455-475.

[13] M.F. Anjum, I. Tasadduq, and K Al-Sultan, Response surface methodology: A neural network approach. Eur J Oper Res 101, 1997, 65-73.

[14] R.M.C. Dawson, D.C. Elliot, W.H. Elliot, andK.M. Jones () Data for Biochemical Research.(Second edition).Oxford University Press, London, UK, 1969.

[15] R.H. Myers, andD.C. Montgomery, Response surface methodology: Process and product optimization using designed experiments. New York: John Wiley \& Sons, Inc.1995. 